This PDF is a selection from an out-of-print volume from the National Bureau of Economic Research

Volume Title: Tax Policy and the Economy, Volume 5

Volume Author/Editor: David Bradford, editor

Volume Publisher: The MIT Press

Volume ISBN: 0-262-02295-8

Volume URL: http://www.nber.org/books/brad91-1

Conference Date: November 13, 1990

Publication Date: January 1991

Chapter Title: The Role of Tax Rules in the Recent Restructuring of U.S. Corporations

Chapter Author: Myron S. Scholes, Mark A. Wolfson

Chapter URL: http://www.nber.org/chapters/c11267

Chapter pages in book: (p. 1 - 24) 


\section{THE ROLE OF TAX RULES IN THE RECENT RESTRUCTURING OF U.S. CORPORATIONS}

\section{Myron S. Scholes}

Stanford University and NBER

Mark A. Wolfson

Stanford University and NBER

U.S. tax reforms in the 1980 s have changed substantially the relative attractiveness of operating in partnership form relative to corporate form. They have also changed the desirability of debt financing relative to equity financing, both of domestic operations and of foreign subsidiaries. And whereas the 1981 Tax Act encouraged mergers and acquisitions among U.S. corporations, the 1986 Act discouraged such transactions. Moreover, these Acts had the opposite effect on incentives of foreign companies to acquire U.S. businesses. In this paper, we attempt to show that these apparently disparate claims are all implied from a common (and simple) framework. Moreover, we present empirical evidence to support the claims.

\section{CORPORATIONS VERSUS PARTNERSHIPS}

To a degree that is historically unprecedented, the corporate form of organization was made tax disfavored relative to partnerships in the United States with the passage of the 1986 Tax Act. Corporate tax rates 
were set above the rate that applies to high-income individuals on ordinary income (the tax rate that individuals face on partnership income). Moreover, the United States imposes tax at two levels on corporate income, but only one level on partnership income. The second level of tax, at the shareholder level, was increased dramatically with the 1986 Tax Act, relative to ordinary tax rates. This was done by making capital gains taxable at the same rate as ordinary income is taxed (whereas capital gains had previously been taxed at favorable rates) and by eliminating some important opportunities to postpone the shareholder-level tax (such as by eliminating the ability to postpone tax through the use of installment sales of publicly traded securities).

The United States is out of sync with most of the rest of the world in taxing corporate income so heavily relative to noncorporate income. In most other countries, corporate income is taxed more favorably either by allowing shareholders to take a tax credit for corporate taxes they pay indirectly as shareholders, by imposing low shareholder-level tax rates, or by imposing relatively low corporate-level tax rates.

To illustrate the tax-disfavored nature of investing in corporations relative to partnerships in the United States, suppose the corporate tax rate is $35 \%$ and the personal tax rate on partnership income, dividend income, and capital gains, is $30 \%$. Then each dollar of income earned at the partnership level yields a tax obligation of $30 \notin$, whereas, the same dollar of income earned at the corporate level yields corporate tax of $35 \varnothing$, enabling a $65 c$ dividend or capital gain to be "distributed" to the shareholders. This $65 \notin$ dividend or capital gain in turn will trigger an additional $19.5 d$ in personal tax, so the total tax burden on the dollar of corporate income becomes $54.5 \mathrm{c}$.

To put into perspective the significance of the tax disadvantage of the corporate tax treatment, the corporate project must earn $54 \%$ more before tax to yield the same after-tax return to shareholders as the same investment undertaken in partnership form provides to partners. This can be seen by noting that the after-tax returns are equal when

$$
R_{c}\left(1-t_{c}\right)\left(1-t_{\mathrm{s}}\right)=R_{\mathrm{p}}\left(1-t_{\mathrm{p}}\right)
$$

or

$$
\frac{R_{\mathrm{c}}}{R_{\mathrm{p}}}=\frac{1-t_{\mathrm{p}}}{\left(1-t_{\mathrm{c}}\right)}
$$

For $t_{\mathrm{p}}=30 \%, t_{\mathrm{c}}=35 \%$, and $t_{\mathrm{s}}=30 \%,\left(1-t_{\mathrm{p}}\right) /\left[\left(1-t_{\mathrm{c}}\right)\left(1-t_{\mathrm{s}}\right)\right]=1.54$, so $R_{c}$ must exceed $R_{\mathrm{p}}$ by $54 \%$ to yield the same after-tax return to investors. 
The example above overstates the degree to which corporations are tax disfavored relative to partnerships under the 1986 Tax Act. First, unless all corporate profits are distributed to shareholders each period as dividends, the shareholder-level tax can be deferred until shareholders sell their shares. This reduces the present value of the shareholder-level tax. Second, if shareholder tax rates vary over time, shareholders may time their stock sales to coincide with periods of low tax rates. Third, certain shareholders may be able to avoid the shareholder-level tax on capital gains by holding their shares until death or by making a charitable contribution of their shares (although such gifts may trigger the alternative minimum tax). Fourth, shareholders may anticipate that capital gains tax rates will be reduced in the future at a time preceding the date at which they will have sold their shares. And fifth, equity financing is not the only type of financing available to corporations. Many of the financing alternatives reduce the entity-level tax by permitting tax-deductible distributions to capital suppliers. These include debt, employee compensation, leases, and royalties. We will return to this point later.

\section{DEFERRAL}

To illustrate the importance of deferral, suppose the corporation were to pursue a policy of paying no dividends, reinvesting after-corporate-tax profits in the firm. Suppose further that investors were to hold their investment positions for a period of 10 years before selling and triggering a capital gains tax on 10 years of share appreciation. Finally, suppose that the pretax return available on partnership projects is $10 \%$, so that, after tax, partnership investments yield $7 \%$. Then the required beforetax rate of return on corporate projects would become $40 \%$ above the required return on partnership projects. This is down from a $54 \%$ required premium when the shareholder-level tax was paid each period. One way to calibrate the magnitude of the deferral benefit is to note that paying the shareholder-level tax at a $30 \%$ rate at the end of ten years is equivalent to paying the tax at a $23.2 \%$ rate each year. ${ }^{1}$

If the shareholders' investment horizon were to increase to 20 years, the required corporate pretax premium would drop further to $31 \%$. On the other hand, there may be nontax costs associated with extending the investment horizon. To the extent that there are, we overstate the value of tax deferral, and this increases the require premium on corporate projects even further.

1 This can be seen by noting that $R_{c} / R_{\mathrm{p}}=\left(1-t_{\mathrm{p}}\right) /\left[\left(1-t_{\mathrm{c}}\right)\left(1-t_{\mathrm{s}}\right)\right]$, substituting values of 1.4 for $R_{\mathrm{c}} / R_{\mathrm{p}}, 30 \%$ for $t_{\mathrm{p}}, 35 \%$ for $t_{\mathrm{c}}$, and solving for $t_{\mathrm{s}}$. 


\section{FAVORABLE CAPITAL RATES TAX RATES}

If the shareholders' investment horizon were 10 years, but the capital gains tax rate were only $70 \%$ of ordinary tax rates (that is, $30 \%$ of capital gains were excluded from taxable income), the required rate of return on corporate projects would still be $28 \%$ above the required rate on partnership projects. This is down from a $40 \%$ premium when capital gains are subjected to a full tax at ordinary rates.

The calculations above assume that shareholders receive all of their return in the form of capital gains. The required premium on corporate projects increases considerably with the dividend yield. The reasons for this include an increase in the fraction of income taxed at ordinary tax rates (rather than favorable capital gains tax rates) and an acceleration of the payment of the tax (reduced value of deferral).

\section{FOREIGN INVESTORS}

It is worth noting that the tax disadvantage of the corporate form does not apply to all investors. Certain foreign investors, for example, actually find corporations to be the tax-favored organizational form through which to invest in the United States.

To illustrate, suppose a foreign investor faces a home-country tax rate on ordinary income of $50 \%$ and a home-country capital gains tax rate of $0 \%$. The home country taxes ordinary income from U.S. partnerships as the income is earned and grants a tax credit for any U.S. taxes paid. If a partnership generated a pretax return of $10 \%$ on invested capital, a foreign investor in the U.S. partnership would earn $10 \%(1-50 \%)$ or $5 \%$ after tax. ${ }^{2}$

What pretax rate of return would a nondividend-paying U.S. corporation have to earn to provide the same 5\% after-tax return that the U.S. partnership provides? Since the United States exempts capital gains earned by foreign investors, and since there is no U.S. withholding tax when the corporate profits are distributed to foreign investors by way of a sale of stock, the after-tax return to the foreign investor becomes $R_{c}(1-$ $t_{c, \text { US }}$ ). Here, $t_{c \text {, US }}$ denotes the U.S. corporate tax rate and is assumed to be equal to $35 \%$. Then $R_{\mathrm{c}}$ need only be equal to $5 \% /(1-.35)$ or $7.69 \%$ to yield the required $5 \%$ after-tax return to our foreign investors. So, the

2 Since the home country credits any U.S. taxes paid, it does not matter to the foreign investor whether the U.S. tax was paid or not. 
foreign investor would require the U.S. corporation to generate a pretax profit that is $23 \%$ less than would be required of a partnership at the same time that a U.S. investor might require the corporation to earn substantially more than a partnership earns. Note how this phenomenon sows the seeds for conflict in desirable investment strategies among various classes of shareholders.

\section{COMPARISON OF CORPORATIONS AND PARTNERSHIPS BEFORE THE 1986 TAX ACT}

Corporate equity investments were not always so tax disfavored relative to partnerships as they appear to be in the United States today. For example, prior to the 1986 Tax Act, the top personal tax rate on ordinary income was $50 \%$, the corporate tax rate on ordinary income was $46 \%$, and long-term capital gains were taxed at $40 \%$ of ordinary taxes, a maximum rate of $20 \%$. If we once again assume that partnership projects yielded $10 \%$ before personal taxes, and that shareholders defer the shareholder-level tax on capital gains for 10 years, then corporate projects would have to earn only $11 \%$ more pretax profit than partnership projects to yield the same after-tax return to high-income investors.

Or consider the situation in the $1960 \mathrm{~s}$ for investors facing personal tax rates on ordinary income of up to $70 \%$, a capital gains tax rate of up to $35 \%$ (or half of the ordinary tax rate), and a corporate tax rate of $48 \%$. Here we find the required return on corporate projects to be below that on partnership projects. To provide the same after-tax return as a $10 \%$ partnership project, the corporation would only need to earn $8.34 \%$ before corporate tax. This is $17 \%$ less than the required return on partnership projects.

\section{TAX INCENTIVES INTRODUCED BY THE 1986 TAX ACT}

Two types of tax-planning incentives follow from the fact that corporate equity investments are tax disfavored relative to investments that avoid an entity-level tax following the 1986 Tax Act: to undertake activity in the non(regular) corporate form, and to finance corporate activities in ways that avoid as much entity-level tax as possible.

As for the first of these incentives, it is worth noting the explosion of so-called S-Corporation elections (where the corporation chooses to have taxable income passed through to the tax returns of its owners without the payment of an entity-level tax) surrounding year-end 1986. S- 
Corporations are limited liability corporations that are not taxed at the entity level so long as a number of restrictive conditions are met. For all practical purposes, large corporations cannot avail themselves of this status. Whereas 75,000 of such elections were made throughout 1985 , three times this number of elections (or 225,000 ) were made in the 5 weeks surrounding year-end 1986.

Despite the tax advantages of doing so, the vast majority of corporations did not restructure their businesses in ways that would allow them to avoid facing an entity-level tax. There are a host of nontax factors that make this a sensible strategy.

The nontax advantages of operating in corporate form include liquidity, more clearly defined property rights under law, and a more efficient market for organizational control to discipline nonowner management. Moreover, there are both tax and nontax costs to change an entity's legal organizational form. In this respect, there is an important distinction to be drawn between tax planning for a new firm and tax planning for a seasoned firm.

Given a strategy of operating in regular corporate form, there are clear tax implications for corporate capital structure. Note, for example, that if all corporate pretax profit could be distributed to investors in the form of tax-deductible interest, rather than nondeductible dividends and capital gains, the required return on corporate projects would be equal to that on partnership projects. The reason, of course, is that the entity-level tax would be eviscerated under such a capital structure policy.

It should be noted, however, that the tax advantages of debt financing disappear for firms that are unprofitable. For such firms, the interest on debt yields no current tax benefits. It is typically better for such firms to issue securities that are tax favored in the hands of investors, like common or preferred stock. Such securities yield implicit tax deductions to the issuer, because investors are willing to accept lower risk-adjusted expected returns for these tax-favored securities.

\section{MITIGATING ENTITY-LEVEL TAXATION THROUGH INVESTMENT STRATEGIES}

Myriad investment projects yield tax deductions and tax credits that allow the statutory tax to be postponed or eliminated altogether. Examples of such investments include research and development projects, capital intensive projects that yield accelerated depreciation, and oil and gas exploration projects. Because such tax-favored investments bear implicit tax, however, they generally will not result in elimination of an 
entity-level tax. For example, if fully taxable investment projects yield $10 \%$ pretax, while tax-favored investment projects of equal risk that yield no corporate-level taxable income yield $7 \%$ pretax, then the corporation bears an implicit tax at the rate of $30 \%$ on pretax corporate profits. To the extent this implicit tax rate is less than the statutory corporate tax rate, investment in tax-favored assets can succeed in mitigating the entity-level tax on corporate equity investments. But the presence of implicit taxes prevents the entity-level tax from being eliminated.

In fact, the presence of implicit taxes makes it impossible to eliminate the entity-level tax by adjusting the capital structure. For example, debt financing no longer succeeds in distributing corporate profits in a way that avoids the corporate-level tax in the presence of implicit tax. The reason is identical to why debt financing is not desirable when the corporation is unprofitable: that is, interest deductions yield tax benefits only when entity-level taxable income is positive. But when the corporation pursues tax-favored investments, income is not fully (explicitly) taxed. This prevents interest from yielding tax deductions that lead to a full corporate tax reduction.

If the corporation invests in tax-favored assets that bear no explicit tax and only implicit tax, shareholders cannot avoid double taxation. lgnoring nontax factors that influence the desirability of issuing debt, this implies that corporations should avoid investing in tax-favored assets even when they face higher tax rates than other investors in the marketplace.

To see this, note that investing in explicitly taxed assets yielding pretax return $R_{\mathrm{c}}$, financed with debt bearing interest equal to the pretax income on these investments, yields the following return to investors:

Corporate return before interest and taxes

Corporate interest expense

$R_{\mathrm{c}}$

Corporate return after interest expense

Corporate tax

Personal interest income

Personal tax on interest income

Total return to investors after tax

$\left(R_{\mathrm{c}}\right)$

$R_{\mathrm{c}}$

$\left(R_{c} t_{\mathrm{p}}\right)$

$R_{\mathrm{c}}\left(1-t_{\mathrm{p}}\right)$

That is, the entity-level tax is avoided. By contrast, if the corporation invests in explicitly tax-exempt assets bearing implicit tax at rate $t_{1}$, corporate investors earn

$$
R_{\mathrm{c}}\left(1-t_{\mathrm{l}}\right)\left(1-t_{\mathrm{p}}\right)
$$


This is lower than the return on a debt-financed investment in fully taxable assets by fraction $t_{\mathrm{i}}$.

\section{EFFECT OF LIMITS TO DEBT FINANCING}

Although U.S. corporations cannot avoid, by issuing debt, the double taxation of returns on tax-favored projects that bear implicit taxes, this does not imply that tax-favored investments should be avoided by corporations. After all, there are both tax and nontax limitations on debt financing. On the tax side, there is the question of whether the taxing authority will permit unlimited deductibility of interest on debt. In other words, there is always a risk that debt will be recharacterized as equity by the taxing authority (Code Section 385).

As for nontax factors, the secondary market for debt securities is much less liquid than the secondary markets for equity securities. As a consequence, debtholders may require an illiquidity premium to be induced to lend funds to the corporation. Debt may also give rise to significant bankruptcy or workout costs. Although debt financing can also yield nontax benefits relating to management incentives, it is clear that the costs are perceived by corporate managers to overwhelm the benefits at high ratios of debt as a fraction of total capitalization.

\section{EVIDENCE ON DEBT FINANCING}

Net new borrowings by the U.S. corporations exploded in the 1980s. From less than half a trillion dollars of outstanding corporate bonds at year-end 1980, corporate bonds outstanding increased to nearly 600 billion dollars by year-end 1983, to nearly 800 billion dollars by year-end 1985 , and to nearly $\$ 1,400$ billion by year-end 1988 .

At the same time, there was a dramatic reduction in the supply of equity securities. Share repurchases averaged $\$ 37$ billion per year from 1984 to 1986 and amounted to $\$ 54$ billion in 1987 . This compares with only $\$ 5$ billion per year from 1978 to 1983 . Other equity retirements by way of corporate acquisitions from $\$ 15$ billion per year from 1980 to 1983 to $\$ 75$ billion per year from 1984 to 1986 .

lt is interesting to note that the trend toward greater debt financing that occurred in the United States in the 1980s was much less dramatic elsewhere around the world. This is consistent with our argument that the corporate form of organization is simply not (very) tax disfavored in countries other than the United States. 


\section{$X$. INCENTIVES OF U.S. MULTINATIONALS TO INCREASE DEBT FINANCING OF FOREIGN OPERATIONS}

The 1986 Tax Act also encouraged U.S. multinational companies to increase their debt financing of foreign subsidiaries. The 1986 Tax Act made the United States a tax haven relative to many other countries. Because the United States credits foreign taxes paid only up to the U.S. tax rate, the 1986 Tax Act caused many U.S. multinationals to face binding foreign tax credit limitations. This means that U.S. multinationals began to pay tax on foreign income at a rate above the U.S. rate in many circumstances. Just as debt financing of U.S. corporations allows some corporate profits to avoid an entity-level tax, so debt financing of foreign operations allows some foreign profits to avoid being taxed locally at tax rates above the U.S. corporate rates.

\section{THE EFFECTS OF THE 1981 AND 1986 TAX ACTS ON MERGERS AND ACQUISITIONS}

The 1981 Tax Act encouraged mergers and acquisitions in several ways. The introduction of the accelerated-cost-recovery-system (ACRS) depreciation provided incentives to "step up" the basis of depreciable assets and to change depreciation schedules to ones that were much more highly accelerated than existed previously. In addition, the Installment Sales Revision Act passed in October of 1980 promoted asset sales by making installment notes a more effective way of reducing the tax costs relating to depreciation recapture and capital gains than previously was the case.

The introduction of ACRS depreciation in conjunction with making investment tax credits more generous in 1981 also gave rise to an increase in net operating loss and tax credit carryforwards on corporate balance sheets. This along with very high interest rates encouraged mergers and acquisitions. High interest rates are relevant because carryforwards diminish in value when discount rates are high.

In contrast to the $1981 \mathrm{Act}$, the 1986 Tax Act discouraged asset sales among domestic taxpayers (but did not discourage such transactions between domestic sellers and foreign buyers as we will see later) in a number of important respects:

- by reducing tax rates, thereby reducing the size of the potential gains from stepping up asset basis; 
- by eliminating the so-called General Utilities doctrine, thereby eliminating the opportunity to avoid a corporate-level tax on capital gains in the event of corporate liquidation;

- by introducing less generous depreciation schedules;

- by introducing more stringent rules regarding the availability of net operating loss and other tax attribute carryforwards in the event of merger;

- by increasing the capital gains tax rate at both the corporate and personal levels;

- by reducing substantially the ability to use installment sales to postpone taxes; and

- by increasing the amount of ordinary income that must be recaptured in a corporate liquidation.

As for the evidence, Table 1 displays annual merger and acquisition activity between 1970 and 1987 in three ways: in nominal dollars, in constant 1986 Consumer Price Index (CPI) dollars, and in dollars of constant 1986 Standard \& Poor's (S\&P) 500 index of stock prices. Note the near doubling of activity between 1980 and 1981 despite weakness in the U.S. economy around this time. This increase in activity is especially impressive given that the Act was not signed into law until August 1981 and the President's proposal was not made until March 1981.

In fact, the activity in the first quarter of 1981 was no greater than that in the fourth quarter of 1980 . But there was a doubling in the dollar value of activity in the second quarter and another $40 \%$ increase in the third quarter.

Note further that the average level of activity increased fivefold in nominal dollar terms between 1970-1980 and 1981-1986. The increase in constant CPI dollars was threefold, and there was a doubling in volume even after adjusting for the increase in the level of stock prices.

Whereas the 1981 Tax Act is associated with an increase in merger activity, the 1986 Act should have discouraged transactions among U.S. businesses. However, taxpayers were given a one-quarter window of opportunity to undertake transactions prior to the effective date of the 1986 Tax Act.

Table 2 shows two things. First, there was a bulge in activity during the fourth quarter of 1986 . The volume was a record in nominal, real, and S\&P 500 -adjusted dollars for at least the preceding 50 years. The volume of activity exceeded the average over the eight surrounding quarters by $85 \%$. Second, the table reveals a decline in activity over the four quarters of 1987 relative to the four quarters preceding the passage of the 1986 Act by $20 \%$ in nominal dollars, $23 \%$ in constant CPI dollars, and $38 \%$ in 
TABLE 1

Merger and Acquisition Values: Nominal Dollar, Constant Dollar, and Constant Stock Index Amounts: Annual Figures, 1968-1987

\begin{tabular}{cccc}
\hline Year & $\begin{array}{c}\text { Nominal dollar } \\
\text { value of } \\
\text { M\&A activity } \\
\text { (\$billions) }\end{array}$ & $\begin{array}{c}\text { Constant 1986 } \\
\text { dollar value } \\
\text { of M\&A activity } \\
\text { (\$billions) }\end{array}$ & $\begin{array}{c}\text { Constant 1986 S\&P } \\
\text { 500 index value } \\
\text { of M\&A activity } \\
\text { (\$billions) }\end{array}$ \\
\hline 1968 & 43.61 & & \\
1969 & 23.71 & & \\
1970 & 16.42 & 42.48 & 86.90 \\
1971 & 12.62 & 31.15 & 58.44 \\
1972 & 16.68 & 39.62 & 64.93 \\
1973 & 16.67 & 37.42 & 76.01 \\
1974 & 12.47 & 25.75 & 77.32 \\
1975 & 11.80 & 22.23 & 53.33 \\
1976 & 20.03 & 35.77 & 73.12 \\
1977 & 21.94 & 37.09 & 86.28 \\
1978 & 34.18 & 53.93 & 126.15 \\
1979 & 43.54 & 63.06 & 135.66 \\
1980 & 44.35 & 58.88 & 104.36 \\
1981 & 82.62 & 100.04 & 204.46 \\
1982 & 53.76 & 61.52 & 109.57 \\
1983 & 73.08 & 80.45 & 121.59 \\
1984 & 122.22 & 129.02 & 191.36 \\
1985 & 179.77 & 183.23 & 212.97 \\
1986 & 201.37 & 201.37 & 201.37 \\
1987 & 174.99 & 168.77 & 166.30 \\
Avg 1970-1980 & 22.79 & 40.67 & 85.68 \\
Avg 1975-1980 & 29.30 & 45.16 & 96.48 \\
Avg 1981-1986 & 118.80 & 125.94 & 173.55 \\
$1981-86 / 1975-80$ & 4.05 & 2.79 & 1.80 \\
$1981-86 / 1970-80$ & 5.21 & 3.10 & 2.03 \\
\hline & & & \\
\hline & & & \\
\hline
\end{tabular}

Sources: W.T. Grimm (Mergerstat) for 1968-1985 nominal values; Mergers $\mathcal{E}$ Acquisitions for 1986-1987 nominal values; 1985 Economic Report of the President Industry Week for consumer prices; $1985-1987$ Ibbotson Associates (Stocks, Bonds, Bills and Inflation) for S\&P 500 index values.

constant S\&P 500 dollars. Moreover, Table 2 ignores the secular trend in merger and acquisition activity. If the series is detrended using data in the 1970 s, the decline in activity in 1987 becomes $37 \%$ in nominal dollars, $32 \%$ in constant CPI dollars, and $45 \%$ in constant S\&P 500 dollars.

The decline in merger and acquisition activity in 1987 is all the more impressive given that it includes leveraged buyouts. Given the enhanced tax advantages of debt financing introduced by the 1986 Tax Act, 
TABLE 2

Merger and Acquisition Values: Nominal Dollar, Constant Dollar, and Constant Stock Index Amounts Quarterly Figures:

1985-4 through 1987-4

\begin{tabular}{|c|c|c|c|c|c|c|}
\hline \multirow[b]{2}{*}{ Quarter } & \multicolumn{6}{|c|}{ Transactions between U.S. companies only } \\
\hline & $\begin{array}{c}\text { Nominal } \\
\text { amount } \\
\text { (\$billions) }\end{array}$ & $\begin{array}{c}\text { Rank } \\
\text { excl } \\
86-4\end{array}$ & $\begin{array}{l}\text { Constant } \\
87-4 \text { CPl } \\
\text { amount } \\
\text { (\$billions) }\end{array}$ & $\begin{array}{c}\text { Rank } \\
\text { excl } \\
86-4\end{array}$ & $\begin{array}{c}\text { Constant } \\
87-4 \text { S\&P } \\
\text { amount } \\
\text { (\$billions) }\end{array}$ & $\begin{array}{c}\text { Rank } \\
\text { excl } \\
86-4\end{array}$ \\
\hline $1985-4$ & 45.93 & 1 & 48.60 & 1 & 57.26 & 1 \\
\hline 1986-1 & 29.97 & 7 & 31.65 & 7 & 32.75 & 5 \\
\hline $1986-2$ & 44.55 & 2 & 47.15 & 2 & 45.97 & 2 \\
\hline $1986-3$ & 34.86 & 4 & 36.65 & 3 & 38.67 & 3 \\
\hline Sum & 155.31 & 14 & 164.05 & 13 & 174.65 & 11 \\
\hline Avg & 38.83 & & 41.01 & & 43.66 & \\
\hline $1986-4$ & 64.65 & & 67.44 & & 68.03 & \\
\hline $1987-1$ & 21.66 & 8 & 22.38 & 8 & 18.78 & 8 \\
\hline $1987-2$ & 32.97 & 6 & 33.63 & 6 & 27.20 & 6 \\
\hline $1987-3$ & 33.66 & 5 & 33.96 & 5 & 26.04 & 7 \\
\hline $1987-4$ & 35.82 & 3 & 35.82 & 4 & 35.82 & 4 \\
\hline Sum & 124.11 & 22 & 125.79 & 23 & 107.84 & 25 \\
\hline Avg & 31.03 & & 31.45 & & 26.96 & \\
\hline Prob $^{1}$ & & .1714 & & .1000 & & .0286 \\
\hline
\end{tabular}

1 Prob denotes the probability that the sum of the ranks in the four quarters preceding $1986-4$ could be as low or lower than the sum of the ranks in the four quarters succeeding 1986-4 by chance alone.

Sources: Mergers \& Acquisitions for nominal values; Industry Week for consumer prices; Ibbotson Associates (Stocks, Bonds, Bills and Inflation) for S\&P 500 index values.

the incidence of leveraged buyouts would not necessarily be expected to fall. Indeed, the resurgence of acquisition activity in 1988 is heavily weighted toward highly leveraged transactions. But another important component of acquisition activity that has been on the rise since 1986 is foreign acquisitions of U.S. businesses. As explained next, this is quite consistent with the incentives provided by the 1986 Tax Act.

\section{INVESTMENT AND REPATRIATIONS POLICIES FOR MULTINATIONAL CORPORATIONS FACING WORLDWIDE TAX SYSTEMS}

Although tax systems around the world have a great deal in common, they also differ from one another along a variety of dimensions: marginal 
tax rates can vary from essentially $0 \%$ in certain tax haven countries to well over $60 \%$ in certain high-tax countries; the definition of income can vary dramatically from country to country; the use of nonincome taxes can vary substantially; taxpayers may be taxed only on domestic income or on worldwide income.

To avoid double taxation of income (once in the host country and once in the home country), countries that tax worldwide income also provide a tax credit for foreign taxes paid. But countries differ in their generosity regarding foreign tax credits. Moreover foreign tax credits typically apply only to income taxes. Value added taxes, for example, are not refundable via foreign tax credits in most countries, including the United States. Instead, any value added tax paid is allowed only to be taken as a tax deduction, and as a result, only the fraction of the nonincome tax paid equal to the taxpayer's marginal income tax rate will effectively be refunded. Just as with value added taxes, implicit taxes paid in a foreign tax jurisdiction on tax-favored investment are often not refundable. By implicit taxes, we mean the reduced level of pretax return the investor earns by investing in tax-favored assets that result from competition for the right to own such assets.

For example, a tax-sheltered investment made by a foreign investor in the United States prior to the 1986 Tax Act might result in no payment of explicit tax to the U.S. Treasury Department. Competition for the right to hold such assets would cause the pretax return available on the investment to be less than that available on less tax-favored assets. The reduced pretax return represents an implicit tax paid by the investor. On repatriation of U.S. earnings back to the tax home of the foreign investor, the foreign investor may be subjected to taxation on the income earned in the United States, but since no explicit U.S. tax was paid, the investor would receive no foreign tax credit. On the other hand, the implicit tax paid will imply a reduced level of income available for repatriation and therefore a reduced level of home-country taxable income. As such, the implicit tax will give rise to a tax deduction (but not a credit) in the home country.

Prior to the Tax Reform Act of 1986, the availability of generous investment tax credits and highly accelerated depreciation made many investments in the United States highly tax favored. As a result, such investments bore a high level of implicit taxes. Moreover, U.S. marginal tax rates were roughly of the same order of magnitude as most other industrialized countries over this period of time. To the extent that implicit taxes are not completely recoverable from their home country on repatriation of profits from U.S. investment, foreign investors were disadvantaged relative to U.S. investors during the 1981-1986 period. This is explained more fully below. 
The 1986 Tax Act favors foreign investment in the United States in several ways. It taxes many U.S. investments much less favorably relative to ordinary income-producing assets, such as bonds, thereby eliminating much of the implicit tax on active investments. The Act also reduced U.S. tax rates relative to those in most of the other industrialized countries. Finally, foreign investors in many countries do not face double taxation of corporate profits as we illustrated earlier. Since the 1986 Tax Act increases the shareholder-level tax to U.S. investors by more than it increases the shareholder-level tax to many foreign investors (recall that the United States does not tax capital gains from the sale of corporate stock by foreign investors), foreigners should find U.S. investments relatively attractive now.

Because income from foreign passive investments, like interest income, often escapes taxation in the foreign country, whereas income from active investments, like operating a business, does not, the pretax return on passive investments is typically less sensitive to local tax rates than is the pretax return on active investments. This means that in countries where the statutory tax rate is low, marginal investments by local residents will typically be in passive assets since the rate available on them will exceed the pretax rate on active assets in such countries. ${ }^{3}$ In addition, the ability of foreigners to invest in active assets at a low marginal tax rate, until profits are repatriated to the home country, will cause foreign investors to be the marginal players in active assets.

The primer that follows develops optimal investment and reinvestment policies for multinational firms facing a worldwide tax structure similar to that in existence in the United States. To keep things simple, only two tax jurisdictions are considered, so issues relating to country-by-country versus worldwide foreign tax credit limitations do not arise. In addition, only two kinds of assets are considered: active and passive.

Suppose that you can invest abroad to earn at the rate of $R_{\mathrm{f}}$ pretax. The local tax rate is $t_{i}$. Each unit of capital invested abroad then grows at rate $R_{f}\left(1-t_{f}\right)$ or $r_{f}$ each year before considening any additional home-country tax on repatriation.

The home-country tax rate is $t_{\mathrm{d}}$. Assume that $t_{\mathrm{d}}>t_{\mathrm{f}}$. Taxable income earned abroad will be taxed in the home country on repatriation (that is, a worldwide tax system is assumed), but a foreign tax credit will be allowed for foreign taxes paid. On repatriation, then, the foreign invest-

${ }^{3}$ Naturally, to avoid arbitrage possibilities, this requires an inability to effect costlessly short sales of active assets in the low-tax country for which an ordinary tax deduction can be taken on any losses from holding the short position. 
ment will attract additional tax at the rate of $t_{d}-t_{f}$ on all taxable income generated abroad.

If home-country investment yields $R_{\mathrm{d}}$ pretax each period, under what conditions is investing abroad preferred to investing in the home country? This can be determined as follows.

After-tax accumulation from investing $n$ periods abroad, followed by repatriation to the home country (per unit of domestic currency invested):

1. Local after-tax accumulation in $n$ years:

2. Total foreign taxable income

- Except for initial investment, each unit of after-tax income is the result of generating $1 /\left(1-t_{t}\right)$ units of taxable income.

3. Additional domestic tax on repatriation

- All taxable income will be taxed at rate $t_{\mathrm{d}}$ less a foreign tax credit at the rate $t_{\mathrm{f}}$.

4. After-tax accumulation, after tax on repatriation: (1) - (3)

5. How does this compare with domestic investment for $n$ years?

$$
\begin{aligned}
& {\left[1+R_{f}\left(1-t_{f}\right)\right]^{n}=\left(1+r_{f}\right)^{n}} \\
& {\left[\left(1+r_{f}\right)^{n}-1\right] /\left(1-t_{f}\right)}
\end{aligned}
$$

$$
\left(t_{\mathrm{d}}-t_{\mathrm{f}}\right)\left[\left(1+r_{\mathrm{f}}\right)^{n}-1\right] /\left(1-t_{\mathrm{f}}\right)
$$

For $n=1$, foreign investment yields [substituting into (4) and noting that $r_{\mathrm{f}}=R_{\mathrm{f}}\left(1-t_{\mathrm{f}}\right)$ :

$$
1+R_{\mathrm{f}}\left(1-t_{\mathrm{d}}\right)
$$

whereas domestic investment yields

$$
1+R_{\mathrm{d}}\left(1-t_{\mathrm{d}}\right)
$$

Over such a short investment horizon, $R_{\mathrm{f}}$ must exceed $R_{\mathrm{d}}$ to favor investment abroad.

For example, suppose an investment of $\$ 6$ million can be made in one of two mutually exclusive projects, one foreign and one domestic. The foreign project is expected to return $25 \%$ after local tax, where the tax rate is also $25 \%$. The domestic project is expected to earn only $20 \%$ after domestic tax, where the tax rate is $40 \%$. If the investment is made 
abroad, assume that all profits and the investment will be repatriated at the end of 1 year. Which project is preferred?

Our calculations above reveal that the decision should be based on whether pretax return $R_{f}$ exceeds pretax return $R_{\mathrm{d}}$. If so, foreign investment is preferred:

$$
\begin{aligned}
& R_{\mathrm{f}}=\frac{r_{\mathrm{f}}}{1-t_{\mathrm{f}}}=\frac{.25}{1-.25}=331 / 3 \% \\
& R_{\mathrm{d}}=\frac{r_{\mathrm{d}}}{1-t_{\mathrm{d}}}=\frac{.20}{1-.40}=331 / 3 \%
\end{aligned}
$$

As a result, it is a matter of indifference! To see this, note that the $\$ 6$ million invested abroad yields taxable income of $\$ 2$ million, tax of $\$ 0.5$ million, and after-tax income of $\$ 1.5$ million. This results in a repatriation of $(\$ 6+\$ 1.5$ or $) \$ 7.5$ million. The repatriation triggers additional domestic tax of $(40 \%-25 \%$ or) $15 \%$ on the taxable income of $\$ 2$ million or $\$ 0.3$ million. This leaves $(\$ 7.5-\$ 0.3$ or $) \$ 7.2$ million after repatriation tax. This is equal to a $20 \%$ after-tax increment on the $\$ 6$ million investment, exactly the same as would result from investment in the domestic project.

Now suppose that the investment horizon increases. In fact, let us consider the other extreme (permanent investment abroad versus domestically). Foreign investment is favored when expression (4) $>\left(1+r_{\mathrm{d}}\right)^{n}$. As $n$ becomes large, this condition is satisfied if, and only if, $r_{\mathrm{f}}>r_{\mathrm{d}}$. Recall that for $n=1$, the required condition was $R_{f}>R_{\mathrm{d}}$. So as the investment horizon lengthens, we can have $R_{\mathrm{f}}<R_{\mathrm{d}}$ (that is, pretax rates of return abroad falling short of domestic pretax rates of return) and yet investment abroad will be preferred due to the opportunity to reinvest abroad at higher after-tax rates. This is the condition currently faced by many foreign investors vis-à-vis U.S. investment.

Returning to our earlier example, where $R_{\mathrm{f}}=R_{\mathrm{d}}=331 / 3 \%$ and $t_{\mathrm{f}}=25 \%$ and $t_{\mathrm{d}}=40 \%$, an investment horizon of $n>1$ years would favor foreign investment. Over a 5-year horizon, for example, the foreign investment would result in an after-tax repatriation of $\$ 15.85$ million [substituting into expression (4)], whereas domestic investment would accumulate to $\$ 14.93$ million after tax or nearly $\$ 1$ million less on this $\$ 6$ million investment.

\section{Implicit Taxes and Foreign Investment Incentives: Example}

Suppose you have $\$ 100$ million to invest in one of two mutually exclusive projects: one at home and the other, of equal risk, located in a lower tax-rate foreign country: 


\begin{tabular}{lccc}
\hline & Tax rate & Pretax return & After (local) tax return \\
\hline Home & $55 \%$ & $22 \%$ & $9.9 \%^{2}$ \\
Abroad & $35 \%$ & $20 \%^{1}$ & $13.0 \%^{3}$ \\
\hline
\end{tabular}

1 Implicit tax to invest abroad $=22-20 / 22=9.09 \%$.

$22 \%(1-55 \%)=9.9 \%$.

${ }^{3} 20 \%(1-35 \%)=13.0 \%$.

Why might there exist an implicit tax to investing abroad? There are both tax and nontax reasons. For tax reasons, competition for the right to undertake activity in a low-tax environment can naturally lead to the pretax return being lower in the low-tax-rate environment. As for nontax reasons, low tax rates are typically offered by the local government to lure business that would not otherwise be undertaken in the low-tax jurisdiction.

Where should you invest: at home at $22 \%$ pretax or abroad at $20 \%$ pretax? Note that if the investment horizon were 1 year, investment abroad followed by repatriation to the home country would yield an after-tax return of only $9.0 \%$. This compares unfavorably with the $9.9 \%$ return available by investing at home. The reason is that the income earned abroad is taxed at the higher of the local tax rate and the home country tax rate, so all that matters is the pretax rate of return.

On the other hand, if profits can be reinvested abroad rather than repatriated at the end of 1 year, the repatriation tax of $20 \%$ (that is, $55 \%$ minus $35 \%$ ) is postponed. This improves matters since the funds are reinvested abroad at $13 \%$ rather than at $9.9 \%$. For sufficiently long time horizons, investing abroad dominates investing at home. So where you should invest is a function of the duration of the investment:

\begin{tabular}{lcccc}
\hline \multirow{2}{*}{$\begin{array}{l}\text { Annual after-tax } \\
\text { rates of return }\end{array}$} & \multicolumn{4}{c}{ Repatriate after (years) } \\
\cline { 2 - 5 } & 1 & 5 & 10 & 20 \\
\hline Home & $\mathbf{9 . 9 0 \%}$ & $\mathbf{9 . 9 0 \%}$ & $9.90 \%$ & $9.90 \%$ \\
Abroad & $9.00 \%$ & $9.62 \%$ & $\mathbf{1 0 . 2 7 \%}$ & $\mathbf{1 1 . 1 5 \%}$ \\
\hline
\end{tabular}

Now suppose the implicit tax abroad is made more generous (e.g., via investment tax credits or accelerated depreciation available only locally), holding local after-tax returns constant: 


\begin{tabular}{lccc}
\hline & Tax rate & Pretax return & After (local) tax return \\
\hline Abroad $_{2}$ & $20 \%$ & $16.25 \%$ & $13 \%$ \\
Abroad $_{3}$ & $0 \%$ & $13.00 \%$ & $13 \%$ \\
\hline
\end{tabular}

Now the after-repatriation-tax returns become

\begin{tabular}{|c|c|c|c|c|}
\hline & \multicolumn{4}{|c|}{ Horizon (years) } \\
\hline & 1 & 5 & 10 & 20 \\
\hline Abroad $_{1}$ (implicit 9.09\%) & $9.00 \%{ }^{1}$ & $9.62 \%$ & $10.27 \%$ & $11.15 \%$ \\
\hline Abroad $_{2}$ (implicit tax $26.14 \%$ ) & $7.31 \%$ & $8.07 \%$ & $8.91 \%$ & $10.15 \%$ \\
\hline Abroad $_{3}$ (implicit tax $40.91 \%$ ) & $5.85 \%$ & $6.64 \%$ & $7.59 \%$ & $9.13 \%$ \\
\hline Home & $9.90 \%$ & $9.90 \%$ & $9.90 \%$ & $9.90 \%$ \\
\hline
\end{tabular}

${ }^{1}$ Example: $20 \%(1-35 \%)-20 \%(55 \%-35 \%)=20 \%(1-55 \%)=9 \%$.

Note that the attractiveness of investing abroad decreases as investment incentives are introduced abroad. What's going on? Whereas explicit taxes are eligible for foreign tax credit, refundable dollar for dollar by the home country, implicit taxes are not. Instead, implicit taxes, by reducing pretax income, give rise to tax deductions at home rather than to tax credits. At a $55 \%$ home-country tax rate, $45 \%$ of the implicit tax is not refunded. So it is expensive for foreign investors to invest in assets that yield a lot of implicit tax.

Whereas under implicit tax regime 1, investing abroad for 20 years beats investing at home by $\$ 168$ million (in 20 years), investing abroad under implicit tax regime 3 loses to investing at home by $\$ 87$ million! And this, despite the fact that foreign investments earn $13 \%$ after local tax under both regimes.

Now suppose that the home country is Japan. The foreign country in regime 1 is the United States after the 1986 Tax Act: the tax rate is roughly $35 \%$ and most operating assets in the United States do not bear much implicit tax compared to what they used to with investment tax credits and more rapid depreciation allowances. The foreign country in regime 3 is the United States following the 1981 Tax Act: investment tax credits and accelerated-cost-recovery-system (ACRS) depreciation made new investments largely tax exempt.

What does the foregoing analysis suggest about foreign investment incentives in the United States in 1981 and 1986? They were reduced and increased, respectively.

Next, we turn to empirical evidence to test whether foreign direct incentives to purchase U.S. interests increased following the introduc- 


\section{TABLE 3}

Quarterly Merger and Acquisition Values: Nominal Dollar, Constant Dollar, and Constant Stock Index Amounts: 1985-4 Through 1987-4

\begin{tabular}{|c|c|c|c|c|c|c|}
\hline \multirow[b]{2}{*}{ Quarter } & \multicolumn{6}{|c|}{ U.S. purchase by non-U.S. companies only } \\
\hline & $\begin{array}{l}\text { Nominal } \\
\text { amount } \\
\text { (\$billions) }\end{array}$ & $\begin{array}{c}\text { Rank } \\
\text { excl } \\
86-4\end{array}$ & $\begin{array}{l}\text { Constant } \\
87-4 \text { CPI } \\
\text { amount } \\
\text { (\$billions) }\end{array}$ & $\begin{array}{l}\text { Rank } \\
\text { excl } \\
86-4\end{array}$ & $\begin{array}{c}\text { Constant } \\
87-4 \text { S\&P } \\
\text { amount } \\
\text { (\$billions) }\end{array}$ & $\begin{array}{c}\text { Rank } \\
\text { excl } \\
86-4\end{array}$ \\
\hline $1985-4$ & 2.13 & 8 & 2.25 & 8 & 2.66 & 8 \\
\hline $1986-1$ & 3.27 & 6 & 3.45 & 6 & 3.57 & 6 \\
\hline $1986-2$ & 2.87 & 7 & 3.04 & 7 & 2.96 & 7 \\
\hline $1986-3$ & 3.43 & 5 & 3.60 & 5 & 3.80 & 5 \\
\hline Sum & 11.70 & 26 & 12.35 & 26 & 12.99 & 26 \\
\hline Avg & 2.93 & & 3.09 & & 3.25 & \\
\hline $1986-4$ & 15.52 & & 16.19 & & 16.33 & \\
\hline 1987-1 & 10.66 & 3 & 11.01 & 3 & 9.25 & 2 \\
\hline $1987-2$ & 10.98 & 2 & 11.20 & 2 & 9.06 & 3 \\
\hline $1987-3$ & 12.82 & 1 & 12.93 & 1 & 9.92 & 1 \\
\hline $1987-4$ & 9.43 & 4 & 9.43 & 4 & 9.43 & 4 \\
\hline Sum & 43.89 & 10 & 44.57 & 10 & 37.66 & 10 \\
\hline Avg & 10.97 & & 11.14 & & 9.42 & \\
\hline Prob $^{1}$ & .0143 & & .0143 & & .0143 & \\
\hline
\end{tabular}

1 Prob denotes the probability that the sum of the ranks in the four quarters preceding 1986-4 could be as high or higher than the sum of the ranks in the four quarters succeeding 1986-4 by chance alone.

Sources: Mergers \& Acquisitions for nominal values; Industry Week for consumer prices; Ibbotson Associates (Stocks, Bonds, Bills and Inflation) for S\&P 500 index values.

tion of the Tax Reform Act of 1986. In particular, we compare merger and acquisition activity between U.S. companies to that in which nonU.S. companies are represented on the buy side (see Table 3 ) around the time of the passage of the 1986 Act in the United States.

The dollar volume of acquisitions of U.S. firms by U.S. companies increased by $85 \%$ during the fourth quarter of 1986 relative to the average during the eight quarters surrounding this period. More precisely, it increased by $66 \%$ in the fourth quarter of 1986 relative to the average over the four preceding quarters. Then acquisitions dropped over the four quarters of 1987 to a level roughly $20 \%$ below that in the four quarters preceding 1986-4.

In comparison, the dollar value of U.S. acquisitions by non-U.S. companies in $1986-4$ increased $430 \%$ to $\$ 15.52$ billion relative to the average 
over the preceding four quarters of $\$ 2.93$ billion. ${ }^{4}$ The level of activity during the fourth quarter of 1986 alone exceeded by $39 \%$ the average annual dollar volume of such activity recorded by $W$. T. Grimm and Company in their annual Mergerstat volume for the 1981-1985 period.

Moreover, while the level of acquisitions activity declined over the four quarters of 1987 , relative to $1986-4$, to $\$ 11$ billion per quarter, the level of acquisitions in the four quarters of 1987 was 3.74 times as high as during the four quarters preceding 1986-4. ${ }^{5}$ Using a simple rank-sum test, the ranking differences (in nominal dollars, constant dollars, or adjusted for changes in the S\&P 500 stock index) could have occurred by chance with probability equal to only .0143 .

This evidence is quite consistent with the 1986 Tax Reform Act's having stimulated foreign demand for U.S. business. Moreover, the increase in foreign demand for U.S. businesses was approximately offset by the decrease in domestic demand for U.S. businesses. That is, whereas U.S. purchases of U.S. businesses dropped by roughly $\$ 8$ billion per quarter over the eight quarters surrounding the passage of the 1986 Tax Act, non-U.S. purchases of U.S. businesses increased by roughly $\$ 8$ billion per quarter. Absent a consideration of how changes in tax rules affected domestic and foreign investors differently, one might have concluded, incorrectly, that the 1986 Act was accompanied by only a transitory shift in demand for mergers and acquisitions during the fourth quarter of 1986.

The argument that the 1986 Tax Act should have increased foreign investment in the United States due to the elimination of tax preferences such as investment tax credits and accelerated depreciation runs in reverse in 1981. The Economic Recovery Tax Act (ERTA) of 1981 accelerated depreciation schedules sharply and liberalized investment tax credits somewhat. It is worth noting that foreign acquisitions dropped very sharply in the post-ERTA period, both in absolute dollar terms and relative as percentage of total acquisitions. Whereas foreign acquisitions of U.S. companies as a percentage of total acquisitions was less than $8 \%$ in the post-ERTA/pre-1986 Tax Reform Act period, it was over $20 \%$ of the total both immediately before ERTA and immediately after the 1986 Tax Act.

The analysis above ignores other factors that may have contributed to the surge in foreign acquisitions of U.S. businesses in the fourth quarter

${ }^{4}$ The increase is $424 \%$ in real terms and $402 \%$ adjusted for changes in the level of the S\&P 500 stock index.

${ }^{5}$ Postreform activity was 3.61 times as high in constant dollar terms and 2.90 times as high adjusted for changes in the level of the S\&P 500 stock index. 
of 1986. For example, concern by foreign investors over increasing trade restrictions may have prompted acquisitions by foreign manufacturers that sell to U.S. consumers. Another factor is the changes in the magnitude of the trade deficit, although this is not entirely independent of the amount of foreign acquisitions. A related factor is currency exchange rates. Several recent papers document an association between foreign direct investment in the United States and the exchange rate between the dollar and other major foreign currencies. ${ }^{6}$ In particular, foreign direct investment apparently increases when the dollar is relatively weak, and conversely, although this would not be expected in perfect capital markets.

What is particularly interesting is that the dollar was relatively very strong during the several years immediately following the passage of the 1981 Tax Act and was very weak in the period surrounding the 1986 Tax Act. Consequently, we are faced with an identification problem in sorting out the independent contribution of tax rule changes and exchange rate changes on acquisition behavior of foreign investors.

But it is also interesting to note that Froot and Stein (1989) find that the relation between exchange rates and foreign direct investments in the United States applies to the manufacturing sector but not the nonmanufacturing sector. Since it is the manufacturing sector where the investment tax credit and depreciation rule changes are most important, this lends further credence to the role of taxes.

In addition, the weakness of the dollar surrounding passage of the 1986 Tax Act began in 1985. The fact that such a dramatic shift in foreign acquisition activity began during the fourth quarter of 1986 rather than earlier is further evidence suggesting the importance of taxes.

It is also worth noting that Froot and Stein find that the relation between foreign direct investment and exchange rates is not significant for the United Kingdom, Canada, or Japan. And although it is significant for West Germany, the coefficient is only one-ninth as large as for the United States. The one indication in Froot and Stein that exchange rates are important in explaining foreign direct investment in the United States is that the relation holds strongly during the 1970 s, where tax changes do not seem terribly significant in the United States.

${ }^{6}$ For example, see Caves, Richard E. (1988). "Exchange-Rate Movements and Foreign Direct Investments in the United States." Discussion Paper No 1383, Harvard Institute of Economic Research, May; Froot, Kenneith A., and Stein, Jeremy C. (1989). "Exchange Rates and Foreign Direct Investment: An Imperfect Capital Markets Approach." Unpublished working paper, February 19; Slemrod, Joel B. (1989). "Tax Effects on Foreign Direct Investment in the U.S.: Evidence from a Cross-Country Comparison." University of Michigan and NBER working paper, January; and Swenson, Deborah. (1989). Unpublished Ph.D. Dissertation, M.I.T. Department of Economics. 
Recent evidence gathered by Deborah Swenson provides further support for our implicit tax hypothesis. Swenson shows that foreign direct investment in the United States occurs most in those industries where explicit tax rates are highest and hence implicit tax rates are lowest, exactly as our model predicts. She also shows that the relation between foreign direct investment and tax rates is stronger involving buyers from countries facing worldwide tax systems than those facing ternitorial tax systems, again as we would predict.

\section{REINVESTMENT OF RETAINED EARNINGS}

The analysis above considered whether new investment should be made abroad or domestically. On the other hand, suppose we have already made investments abroad. Assume further that our tax basis in the investment is $\$ 0$ (e.g., we have already taken tax deductions for amounts equal to our onginal investment). Earnings of $\$ 1$ have been generated, and local taxes of $t_{\mathrm{f}}$ have been paid, leaving retained earnings of $\$ 1-t_{\mathrm{f}}$. Should $\$ 1-t_{\mathrm{f}}$ be reinvested locally or repatriated?

(a) Reinvestment locally for $n$ periods at pretax rate $R_{\mathrm{f}}$ per period yields:

$$
\left(1-t_{f}\right)\left[\left(1+r_{f}\right)^{n} \frac{\left(1-t_{d}\right)}{\left(1-t_{f}\right)}+\frac{\left(t_{d}-t_{f}\right)}{\left(1-t_{f}\right)}\right]-\left(t_{d}-t_{f}\right)
$$

expression (4)

additional domestic tax on repatriation for the $\$ 1$ of taxable income that gave rise to the $\$ 1-t_{\mathrm{f}}$ in retained earnings to begin with.

Conveniently, this simplifies to:

$$
\left(1+r_{\mathrm{f}}\right)^{n}\left(1-t_{\mathrm{d}}\right)
$$

(b) Repatriation of $1-t_{\mathrm{f}}$, after attracting additional domestic tax of $\left(t_{\mathrm{d}}-\right.$ $\left.t_{f}\right)$, invested domestically for $n$ periods yields

$$
\left[1-t_{\mathrm{f}}-\left(t_{\mathrm{d}}-t_{\mathrm{f}}\right)\right]\left(1+r_{\mathrm{d}}\right)^{n}=\left(1+r_{\mathrm{d}}\right)^{n}\left(1-t_{\mathrm{d}}\right)
$$

So here, the optimal policy is to repatriate, rather than reinvest abroad, if, and only if, $r_{\mathrm{d}}>r_{\mathrm{f}}$. Moreover, this is true whether $n$ is small or large. 


\section{REINVEST VERSUS REPATRIATE WITH SUBPART F-TYPE INVESTMENTS}

The analysis above assumed that reinvestment abroad gave rise to domestic tax deferral on all income generated abroad until such income is repatriated. Passive (Subpart F) income is deemed to be repatriated as it is earned. Although this might appear to be disadvantageous relative to non-Subpart $\mathrm{F}$ income, this need not be so.

In particular, suppose that passive income earns the same pretax rate whether invested abroad or domestically (e.g., Eurodollar bonds abroad versus equally risky dollar-denominated bonds domestically). Then $\$ 1$ pretax income abroad, reduced by $t_{f}$ for local tax, and reinvested locally at rate $R$ for $\mathrm{n}$ years (taxed each year domestically as Subpart $\mathrm{F}$ income) yields

$$
\left(1-t_{\mathrm{f}}\right)\left[1+R\left(1-t_{\mathrm{d}}\right)^{n}-\left(t_{\mathrm{d}}-t_{\mathrm{f}}\right)\right.
$$

Additional tax at time $n$ on repatriation attributable to the $\$ 1$ of taxable income that gave rise to the $1-t_{f}$ initial retained earnings.

By contrast, immediate repatriation of $1-t_{\mathrm{f}}$ gives rise to immediate domestic tax of $\left(t_{\mathrm{d}}-t_{\mathrm{f}}\right)$, such that $1-t_{\mathrm{d}}$ gets invested domestically for $n$ periods:

$$
\left(1-t_{\mathrm{d}}\right)\left[1+R\left(1-t_{\mathrm{d}}\right)\right]^{n}
$$

Note that (d) can be expanded to

$$
\left(1-t_{\mathrm{f}}\right)\left[1+R\left(1-t_{\mathrm{d}}\right)\right]^{n}-\left(t_{\mathrm{d}}-t_{\mathrm{f}}\right)\left[1+R\left(1-t_{\mathrm{d}}\right)\right]^{n}
$$

Comparing $\left(\mathrm{d}^{\prime}\right)$ to (c), we see that as long as $t_{\mathrm{d}}>t_{\mathrm{f}}$ (as we have assumed), (c) is larger by an $n$-period after-tax interest factor on the additional tax due on repatriation. In (d), the immediate repatriation strategy, the tax is paid immediately, whereas in (c), the local reinvestment strategy, it is paid (without accretions for interest) in $n$ periods.

\section{INVESTMENT AND REPATRIATION POLICY WHEN THE FOREIGN TAX RATE EXCEEDS THE DOMESTIC TAX RATE}

In the analysis above, comparisons of foreign and domestic investment accumulations were complicated by the fact that repatriation of foreign 
earnings gave rise to an additional tax. When the foreign tax rate exceeds the domestic rate, repatriation triggers no additional tax (assuming that there is no foreign withholding tax). With these assumptions, it is straightforward to verify that foreign investment is preferred to domestic investment, for any length investment horizon, if and only if $r_{\mathrm{f}}>r_{\mathrm{d}}$. The same condition determines whether reinvestment abroad is preferred to repatriation of foreign retained earnings.

\section{CONCLUDING REMARKS}

U.S. tax reforms in the 1980s had profound consequences for optimal investment and financing strategies of both domestic and foreign investors. Evidence indicates that taxpayers can be quite responsive to a change in tax incentives. Although highly leveraged corporations have fallen from favor of late on Wall Street the incentive to distribute corporate profits to investors in tax deductible ways is very strong under the current tax regime. Unless the tax system is changed to make U.S. corporations less tax disfavored relative to partnerships, investment bankers and other organization designers will continue to search for ways to gut the corporate tax without introducing excessive nontax costs. If such strategies are deemed to exact substantial social costs, U.S. legislators might pause to wonder why their tax treatment of corporate profits is so out of step with the way such activities are taxed by the rest of the world. 